\title{
Refuge
}

Canada's Journal on Refugees

revue canadienne sur les réfugiés

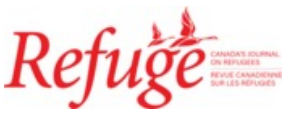

\section{In the Name of Humanitarianism: The Interim Federal Health Program and the Irregularization of Refugee Claimants}

\section{Laura Connoy}

Volume 34, numéro 2, 2018

URI : https://id.erudit.org/iderudit/1055577ar

DOI : https://doi.org/10.7202/1055577ar

Aller au sommaire du numéro

Éditeur(s)

Centre for Refugee Studies, York University

ISSN

0229-5113 (imprimé)

1920-7336 (numérique)

Découvrir la revue

Citer cet article

Connoy, L. (2018). In the Name of Humanitarianism: The Interim Federal Health Program and the Irregularization of Refugee Claimants. Refuge, 34(2), 61-72. https://doi.org/10.7202/1055577ar
Résumé de l'article

De juin 2012 à avril 2016, les demandeurs d'asile ont été confrontés au Canada à une restriction d'accès à la couver-ture sanitaire par le Programme fédéral de santé intérimaire (PFSI). Ces restrictions visaient à protéger l'intégrité du système humanitaire du pays. J'analyse dans cet article la manière dont ont fonctionné ces restrictions et dont elles ont été vécues au quotidien à Toronto dans des lieux fournissant des soins de santé. J'étudie aussi comment le programme humanitaire PFSI peut être compris comme un assemblage favorisant la non-régularité des situations, qui cible et interroge de diverses manières la présence de demandeurs d'asile, et génère ainsi une vulnérabilité, une insécurité et une anxiété. Je conclus ensuite en examinant comment les activistes qui cherchaient à dégager les demandeurs d'asile de toute irrégularité au sein des établissements de santé ont en réalité fermé de véritables voies de transformation sur la route de la justice sociale.
Copyright (c) Refuge: Canada’s Journal on Refugees, 2018

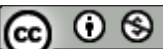

Ce document est protégé par la loi sur le droit d'auteur. L'utilisation des services d’Érudit (y compris la reproduction) est assujettie à sa politique d'utilisation que vous pouvez consulter en ligne. 


\title{
In the Name of Humanitarianism: The Interim Federal Health Program and the Irregularization of Refugee Claimants
}

\author{
LAURA CONNOY ${ }^{1}$
}

\section{Abstract}

Since 1957 Canada's Interim Federal Health Program (IFHP) has provided health-care coverage to refugee populations. However, from June 2012 to April 2016 the program was drastically revised in ways that restricted or denied access to health-care coverage, specifically to refugee claimantspersons who have fled their country and made an asylum claim in another country. One of the main intentions of the revision was to protect the integrity of Canada's humanitarian refugee determination system. However, this had a major unintended consequence: within everyday healthcare places like walk-in clinics, doctor's offices, and hospitals, IFHP recipients were denied access to services, regardless of actual levels of coverage. In this article I analyze how these program restrictions were experienced within Torontos everyday health-care places through the concept of irregularization. I discuss how the IFHP, as a humanitarian health-care program, problematizes the presence of refugee claimants in ways that created experiences of vulnerability, insecurity, and anxiety. Building on this view, I conclude with a discussion of how activists who sought to draw attention to the experiences of refugee claimants in the aftermath of the IFHP revisions closed off truly transformative pathways toward social justice.

\section{Résumé}

De juin 2012 à avril 2016, les demandeurs d'asile ont été confrontés au Canada à une restriction d'accès à la couverture sanitaire par le Programme fédéral de santé intérimaire (PFSI). Ces restrictions visaient à protéger l'intégrité du système humanitaire du pays. J'analyse dans cet article la manière dont ont fonctionné ces restrictions et dont elles ont été vécues au quotidien à Toronto dans des lieux fournissant des soins de santé. Jétudie aussi comment le programme humanitaire FSI peut être compris comme un assemblage favorisant la non-régularité des situations, qui cible et interroge de diverses manières la présence de demandeurs d'asile, et génère ainsi une vulnérabilité, une insécurité et une anxiété. Je conclus ensuite en examinant comment les activistes qui cherchaient à dégager les demandeurs d’asile
(C) Laura Connoy, 2018. This open-access work is licensed under a Creative Commons Attribution-NonCommercial 4.0 International Licence, which permits use, reproduction, and distribution in any medium for non-commercial purposes, provided the original authorship is credited and the original publication in Refuge: Canada's Journal on Refugees is cited.
Cette ouvre en libre accès fait lobjet d'une licence Creative Commons Attribution-NonCommercial 4.o International License, laquelle autorise l'utilisation, la reproduction et la distribution de l'œuvre sur tout support à des fins non commerciales, pourvu que l'auteur ou les auteurs originaux soient mentionnés et que la publication originale dans Refuge: revue canadienne sur les réfugiés soit citée. 
de toute irrégularité au sein des établissements de santé ont en réalité fermé de véritables voies de transformation sur la route de la justice sociale.

$\mathrm{H}$ umanitarianism is typically associated with ideas and practices that aim to alleviate suffering and injustice. However, as Fassin notes, humanitarianism is also founded on difference and inequality. ${ }^{2}$ The actors, policies, practices, documents, and knowledges that constitute humanitarianism work to differentiate and categorize persons seeking access to humanitarian assistance and protection. In this article I analyze how Canada's humanitarian refugee system, and specifically its Interim Federal Health Program (IFHP), works to differentiate and problematize the presence and claims of refugee claimants.

Since 1957 Canada has offered health-care coverage to refugee populations through the IFHP. In 2012 the program was drastically revised in ways that aimed to protect the integrity of Canada's humanitarian refugee determination system, as well as ensure fairness to Canadians and contain financial costs. ${ }^{3}$ Here the goal was to deny access to essential healthcare coverage in order to deter refugee claimants from making a claim within the country and/or to force those within the country to leave more quickly. ${ }^{4}$ The IFHP revision represented one of many moves adopted by the federal Conservative government to regulate refugee claimants. For example, in 2009 visa requirements for Mexican nationals were introduced in order to "reduce the burden" of Mexican claims on the refugee system, 5 and in 2010 the Designated Countries of Origin (DCO) list was introduced, which defines certain countries (including Mexico and Hungary) as respecting human rights, offering state protection, and therefore as less likely to produce refugees. Through this measure, persons claiming asylum from a DCo face stricter asylum measures ${ }^{6}$ and an erosion of their rights. ${ }^{7}$

In order to justify the restrictive revisions to the IFHP, government officials relied upon a construction of refugee claimants as "different" subjects within the context of humanitarian assistance and refugee protection. Offering refugee protection is inherently humanitarian, however, as Casas-Cortes et al. note, protection and support is provided to those who "obey and behave as demanded by the

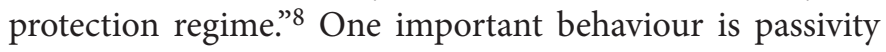
or helplessness. According to Ticktin, "Humanitarianism often requires the suffering person to be represented in the passivity of their suffering," 9 which effectively makes the act of seeking asylum problematic. To make a refugee claim requires moving (and claiming) on one's own volition rather than waiting to be resettled, which positions refugee claimants as practising an "unsavoury" and "dangerous" form of agency, ${ }^{10}$ one that occurs outside regulated refugee pathways.
As a result, and as I discuss below, refugee claimants were targeted as greedy and rule-breaking "bogus" "queue jumpers" who were undeserving of accessing important finite health-care resources. I approach this targeting of presence (i.e., of "being here," or one's concrete locality within space ${ }^{11}$ ) and rights through the concept of irregularization.

Irregularization targets and questions the presence of certain persons as abnormal, out of place, or in other words irregular, regardless of legal status. ${ }^{12}$ In this light, to be irregular, or to be attributed the status of irregularity, is not a legal (i.e., juridical) status, but a standing or positioning $^{13}$ that shapes lived experience by effecting one's ability to make claims, which produces insecurity, vulnerability, and anxiety. Here status (as standing or positioning) alerts us to the processes that hierarchically position persons/groups and attribute identities; it attends to the ways persons are (re)shaped/(re)fashioned in space that exceed the focus simply on law and policy. Irregularization emerges through a complex assemblage of heterogeneous elements (i.e., policies, practices, documents, actors, knowledges, encounters, etc.) that come together in unpredictable, inconsistent, and contradictory ways to problematize the presence of certain individuals/groups as irregular ${ }^{14}$ and to effectively regulate movement and access to services. As stated by O'Connor and Ilcan, assemblages "create events and the possibility of events" and "make a difference or disclose different futures or the possibility of things being other than what they were" within "local sites and social settings." 15 As a status that emerges out of irregularizing assemblages, irregularity can be understood as constituted within everyday encounters and relations; it is contingently configured and enforced by state and nonstate actors to limit access to social resources and to rights. To view irregularization as an assemblage captures well the messiness of the everyday and alerts us to the labour that goes into irregularization, and to the importance of how one's presence within space is encountered and (re)negotiated. As noted by Rygiel, presence is intricately connected with rights, which means targeting and questioning presence interrupts rights and claims to them. ${ }^{16}$ Problematizing presence therefore challenges one's connections with and contributions to the surrounding community as well as their occupation and use of space, which work as foundations to rights and rightsclaiming. ${ }^{17}$ This is a key element of irregularization.

Analyzing the IFHP through the concept of irregularization draws attention to how refugee claimants were restricted or denied access to health-care coverage as a result of their irregularized status within the broader humanitarian realm and within the state. This irregularity was then interpreted, (re)produced, and experienced in contradictory and unpredictable ways within everyday health-care places, such as in Toronto's walk-in clinics, doctor's offices, and hospitals. Here, 
health-care professionals were actively involved in the irregularization of refugee claimants, which in practice restricted or denied access to essential health-care services, regardless of actual levels of coverage. Perhaps the most affected were refugee claimant women, specifically pregnant women, because the IFHP revisions targeted prenatal and postnatal coverage. Women were also affected beyond the health-care context; as detailed below, their asylum claims do not reflect the existing definition of refugee, which compounds their irregularity. In this regard, I illustrate how refugee claimant women experience a gendered form of irregularity within and outside of health care.

In light of the above, I show how Canada's refugee system can be thought of as an irregularizing humanitarian assemblage. In addition to this analysis of regulation and restriction, I also draw attention to the friction and messiness that defines this assemblage ${ }^{18}$ as evident in the forms of resistance that emerged in light of the IFHP cuts. Although this resistance is well-intentioned, I shed critical light on how it closed off transformative pathways to a more socially just healthcare system. In light of the above, the key guiding question of this article is: how is Canada's refugee system irregularizing, and are there gendered effects? In addition, I also ask how are resistance strategies implicated in the maintenance of irregularity? Drawing on critical migration and humanitarianism literature, ${ }^{19}$ this article calls more attention to how refugee claimants are irregularized in Canada and how this affects access to essential health-care services.

This article is organized into four sections. Following a brief explanation of the research methods deployed in this study, I offer an overview of my conceptual framework that connects humanitarianism and irregularization in order to better understand how refugee claimants, and others navigating Canada's humanitarian system, are targeted and questioned in ways that deny or restrict rights and entitlements. I then provide a review of the IFHP which is followed by an empirical analysis of the gendered experiences of irregularity among refugee claimant women, specifically in Toronto's everyday health-care places. I conclude with a discussion of how resistance efforts that sought to "liberate" refugee claimants in Toronto from irregularity affirmed, rather than transformed, existing irregularizing structures.

\section{Methods and Data}

Research data for this article comprise semi-structured interviews conducted with forty-three participants in Toronto, Ontario, from September 2015 to March 2016. Participants included doctors, nurses, lawyers, settlement workers, policy specialists, executive directors, and program managers of refugee agencies, ministry officials, city officials, and refugee claimants. The large majority of the participants were contacted through email and cold-calling, while some were secured through referral. Interview questions focused largely on understandings, interpretations, and experiences of the IFHP and provincial and local initiatives, as well as access to health-care services in the city. I also inquired as to how participants thought barriers and challenges to health-care were produced, (re)negotiated, or transgressed. Interviews were audio recorded and transcribed; iterative analysis of transcripts continued until the emergence of clear themes and commonalities. In addition to the interviews, I also utilized discourse and policy analysis of relevant governmental and non-governmental statements, press releases, policy documents, position papers, and reports. Interpretive analysis followed whereby conceptual links were established and triangulated between participants and relevant documents. The research received approval from the University of Waterloo's Office of Research Ethics and received funding from a Social Sciences and Humanities Research Council (sshrc) Doctoral Fellowship.

\section{The Irregularizing Assemblage of Humanitarianism}

Humanitarianism is generally understood as a response to injustice and suffering in times of crisis or emergency through the provision of relief, such as food aid, infrastructure development, medical assistance, training, education, and refugee resettlement. These actions are "taken in the name of a shared humanity" 20 that aims to save lives and respond to morally compelling crises. Humanitarian responses are informed by principles of neutrality, humanity, and universality ${ }^{21}$ and are expressed in the language of duty, obligation, and responsibility. ${ }^{22}$ However, this affiliation with human welfare tends to gloss over dysfunctional, ineffective, and counterproductive practices, actions, and frameworks that may in fact reproduce inequality and injustice and reduce the rights of refugees. ${ }^{23}$ For example, while the humanitarian practice of self-reliance in Uganda's Nakivale refugee settlement aims to give refugees more control over their own lives, this decontextualized and managerial solution in fact violates the rights of refugees and forces them to participate in an environment where they face isolation, poverty, xenophobia, and inadequate access to social supports. ${ }^{24}$ The development and implementation of humanitarian actions and solutions is largely founded upon de-politicizing and de-historicizing discourses that construct refugees as "victim," who lack "the authority to give credible narrative evidence or testimony about their own condition." 25 This political voicelessness therefore requires the intervention of experts who speak for refugee populations and find solutions for the problems they are fleeing. 26 "Refugee as victim" also positions human beings as having different degrees of power and worth. ${ }^{27}$ Specifically, it creates distinctions between 
"those who have the power to protect, and those who need protection-those who suffer, and those who recognise and address suffering." 28 Scholars are demonstrating how humanitarian practices of differentiation effectively regulate refugees and other (forced) migrant groups. ${ }^{29}$ For example, Walters highlights how zones of humanitarian government differentiate between and regulate racialized bodies to decipher whose life is to be fostered or abandoned. ${ }^{30}$ This article speaks to this relationship between difference and regulation, particularly in relation to refugee claimants in Canada.

Refugee claimants represent one of many categories of persons who seek access to humanitarian protection and assistance provided through Canada's refugee program. In contrast to the refugee, who has proven suffering or fear of persecution, and "refugeeness," being "the institutional, international expectation of a certain kind of helplessness as a refugee characteristic," 31 refugee claimants have yet to prove their suffering, fear, and helplessness. It is this element of "yet to prove" that is of vital importance to discussions of irregularization. The act of making a claim positions refugee claimants away from helplessness and victimhood. Rather, this population tends to be viewed as bypassing regulated pathways to refugee protection; as one lawyer stated, "Canada would like to be selecting its refugees ... and deciding who will be coming and is thereby getting out the message that anybody who arrives in a different way, who's not sitting in a refugee camp hoping that they are going to be one of the chosen few, is somehow doing it wrong, is jumping a queue, is illegal, is bogus, etcetera." ${ }^{2}$ Refugee claimants represent an alternative status, something irregular in the context of "refugeeness." This irregular status renders this population more susceptible to characterizations of "bogusness" "rule breaking" or "queue jumping" in addition to problematizations of presence within space, which interrupts rightsclaims, such as health-care rights and more broadly rights to movement or asylum. ${ }^{33}$ Drawing on Zetter, the label of "refugee claimant" establishes certain assumptions about the characteristics of this population (i.e., bogus queue jumpers), but also "certain assumptions and expectations about humanitarian treatment and responses." 34 As I demonstrate below, the constructed irregularity of refugee claimants within the context of Canada's refugee system worked to justifiably limit humanitarian actions and responses, such as restricted access to health-care coverage and services.

Irregularity is a status, or positioning, of an individual/ group that does not reflect the norm; it is constituted by problematizations of one's presence and emerges through irregularizing assemblages. This definition builds upon the work of Squire, who approaches irregularity as the targeting and control of migrants via "various processes of (ab) normalization and subjectification,"35 and Hepworth who defines irregularity as constituted through legislations, discourses, and encounters that question and render presence as illegitimate, regardless of legal entry and residence within the state. ${ }^{36}$ To approach irregularity as a positioning produced through irregularizing assemblages speaks to the importance of heterogeneous elements (i.e., actors, documents, policies, practices, knowledges, encounters, etc.) that work to question, target, and/or construct the presence of populations as abnormal, out of place, or otherwise irregular, regardless of legal status. In line with O'Connor and Ilcan, ${ }^{37}$ Villegas defines an assemblage as "the coming together of different processes, actors and practices organized through relations of power. Assemblages point to the contingency of how phenomenon, ... are organized." 38 From this definition, assemblage, as it relates to irregularization, can be understood as an ambiguous and unstable form of regulation that emerges through a combination of elements that create inconsistency, unpredictability, and contradiction, in addition to friction and messiness. As Müller argues, assemblage highlights how and why exercises of power emerge and operate, are (precariously) held together, shape space and action, and "fall apart." 39

This conceptualization of irregularity is useful within the context of Canada's humanitarian system because, although refugee claimants are legal temporary residents, they are subject to securitizing and criminalizing measures that problematize their presence, and rights claims and asylum claims, within the state and the everyday. Although not used explicitly, scholars are demonstrating how Canada's humanitarian system "irregularizes" refugee populations, particularly the Roma. ${ }^{\circ}$ In this article, I demonstrate how refugee claimants are irregularized within Canada's everyday health-care places such as doctor's offices, walk-in clinics, and hospitals. This is achieved through a specific focus on the IFHP.

\section{The Interim Federal Health Program and the Protection of Canada's Humanitarian System}

Since 1957 refugees in Canada have received health-care coverage through the IFHP. ${ }^{41}$ This is a federally administered program that was created as an emergency response to meet the needs of resettled refugees, refugee claimants, and other protected persons who were not eligible for provincial or territorial health insurance, or private health insurance. The IFHP pays for basic health-care, preventative/supplemental care, and prescription medications, as well as prenatal and obstetrical care. The coverage provided through the IFHP is equivalent to that provided to citizens and permanent residents on social assistance. However, through a combination of increased program expenses, ${ }^{42}$ and a securitized environment, the federal government opted to reform the IFHP in ways that would modernize it, ensure fairness to Canadians, 
protect public health and public safety, and defend Canada's refugee system while deterring its abuse. ${ }^{43}$ In other words, the goal of the reform was to protect Canada's refugee system and safeguard finite health-care resources for citizens, permanent residents, and "legitimate" refugees. According to Conservative MP Scott Armstrong, "bogus" claimants "soak up our generous benefits and try to jump the queue because they did not want to wait in line and follow the rules like everyone else. While here, these bogus claimants have access to our generous taxpayer-funded health care system and our welfare benefits." 44 Chris Alexander, minister of citizenship and immigration from 2013 to 2015, similarly stated, "Bogus asylum seekers are not entitled to the same benefits as taxpaying Canadians or genuine refugees." 45 For him, "simply arriving on our shores and claiming hardship isn't good enough. This isn't a self-selection bonanza or a social program buffet." 46 In these quotes, refugee claimants are problematized as disingenuous, selfish, and threatening, and therefore as undeserving of services. These framings of refugee claimants, in direct contrast to citizens, permanent residents, and "legitimate" refugees, justified restricted access to health-care coverage offered through the IFHP. Arguably, the cuts to the IFHP also reinforced the imagined "otherness" of refugee claimants, as persons who do not necessarily fit within Canada's refugee program.

The aforementioned cuts to the IFHP were announced on 25 April 2012, executed through Order-in-Council P.C. 2012-433, the Order Respecting the Interim Federal Health Program, 2012. Alongside a 28 June 2012 Order-in-Council P.C. 2012-945, these orders repealed and replaced the original 1957 order and effectively instated a new IFHP on 30 June 2012 that would drastically reduce the amount of coverage provided to refugee claimants in the country. 47 The new IFHP introduced three hierarchical categories of health-care coverage: expanded health-care coverage, basic health-care coverage, and public health or public safety (PHPS) healthcare coverage. Each category offered different types of coverage based upon one's status, country of origin, and mode of entry. Refugee claimants from a non-DCO country received basic health-care coverage, which includes medical services and access to diagnostic tests and hospital services "if they are of an urgent or essential nature" and no medication/ immunizations except to prevent or treat a PHPS threat; 48 for pregnant women, consultation fees for the initial assessment and follow-ups, required tests, cost of delivery at a per diem rate, and post-partum follow-ups for twenty-eight days after delivery were covered, but medication was not covered unless it was for a PHPS risk. 49 PHPS coverage applied to refugee claimants from a DCO country and provided no services or medications unless to prevent or treat a PHPS threat or concern; ${ }^{50}$ this included pregnant women. ${ }^{51}$ These forms of coverage could change, depending on where one was positioned within the claims process, meaning that refugee claimants could be eligible for different types of health-care coverage at different times. Compounded by the limited amount of information that was provided to health-care professionals, this confusing approach to refugee healthcare coverage meant that doctors had to navigate a "complex matrix of impenetrable and incomprehensible degrees of coverage," leading many to "just throw up their hands and give up." ${ }^{2}$ In practice this meant that even people with health-care coverage were sometimes denied health-care services or faced restrictions to services in unpredictable, contradictory, and inconsistent ways.

Facing the severity of the IFHP cuts, a group of activists and refugee claimants launched a Federal Court Charter challenge. The Canadian Doctors for Refugee Care, the Canadian Association of Refugee Lawyers, Justice for Children and Youth, and two refugee claimants, Daniel Garcia Rodriguez and Hanif Ayubi, requested a judicial review of the federal government's decision to reduce IFHP coverage, arguing it was inconsistent with Canada's international obligations to refugees and in violation of section 7 (the right to life and security of the person), section 12 (cruel and unusual treatment), and section 15 (discrimination) of the Canadian Charter of Rights and Freedoms ${ }^{53}$. On 4 July 2014, the Court ruled the cuts were in violation of sections 12 and 15 of the Charter and ordered the government to introduce a revised program within four months. On 4 November 2014 the government introduced the "temporary"IFHP, since the federal government appealed the court decision.

The "temporary" program restored full coverage to pregnant women and children and gave all refugee claimants, regardless of country of origin, coverage for medical care, diagnostics, hospital services, and prescriptions to treat PHPS threats. ${ }^{54}$ However, the complexity of the program intensified through the introduction of six types of health-care coverage, with refugee claimants receiving "type three" coverage. This confusion led even more health-care professionals to problematize the presence of refugee claimants within everyday health-care places and to deny services to this population.

Below I offer an empirical analysis of the IFHP within Toronto's everyday health-care places from June 2012 to April 2016. Within these places, health-care professionals were forced to interpret the IFHP with limited information and within a national context that was working to irregularize refugee claimants. I pay specific attention to female refugee claimants who were actively navigating Canada's humanitarian system during this time to highlight the gender politics that define humanitarianism and forced migration 55 and demonstrate the specific gendered experiences of irregularity within everyday health-care places. 


\section{A Gendered Approach to Irregularization: Female Refugee Claimants and Access to Health Care}

In Canada the most common reason women seek refuge is to escape gender persecution, which includes forced marriage, female genital cutting, and domestic abuse, the last of which accounted for more than half of the claims made by women between January 2013 and September $2017 .{ }^{56}$ However, claims based on gender persecution do not necessarily reflect the definition of refugee set forth by international and national refugee systems. ${ }^{57}$ An executive director of a women's organization in Toronto elaborates on women's experiences seeking refugee protection:

The refugee system is not the most advantageous for the most part for women who experience violence because ... the international definition of what makes a refugee is really based on a male definition of experiences of power, violence, state coercion. And statistically at the moment, the greatest number of women affected by violence are affected by domestic violence globally and it drives their migration ... what we traditionally think of as the refugee and what the legal system traditionally thinks of as the refugee which is the lone man of conscience against the state, most women don't meet that definition, so the women who come here, every aspect of their situation is irregular to that system..$^{8}$

This mirrors the views of Salcido and Menjívar, who explain that many women are unable to obtain refugee protection because the fundamental need to prove persecution is "more in line with what are perceived to be men's experiences than with what are perceived to be women's experiences." 59 This irregularity of women results in denied refugee protection, increased vulnerability, and restricted rights, entitlements, and protections. ${ }^{60}$ The gendered experience of irregularity is important to consider in the Canadian context, since there has been a steady increase in the number of women making refugee claims over the past decade. ${ }^{61}$ As a result of not reflecting the definition of refugee, many women have to navigate the system through alternative streams such as the Humanitarian and Compassionate $(\mathrm{H} \& \mathrm{C})$ claim. However, the $\mathrm{H} \& \mathrm{C}$ decision can take years, and applicants must meet requirements such as health standards in order to be successful. ${ }^{62}$ It is important to note, however, that without IFHP coverage these health requirements may be difficult to meet. ${ }^{63}$ While refugee claimant women are irregularized through established international and national definitions of refugee, their presence is also rendered problematic within everyday health-care places. For those women who are pregnant, which according to a doctor is "a common presentation," 64 they are subject to increased targeting and questioning.
Within a couple of years, the coverage provided to pregnant claimants shifted from denied coverage for prenatal and postnatal care to DCO claimants, to increased coverage for prenatal and postnatal care services but restricted access to medication, regardless of country of origin. While this shift created confusion among health-care professionals, perhaps what was most problematic was the fact that coverage could still change as a result of a refugee hearing decision. For many obstetricians, they came to problematize the presence of women with IFHP coverage within their offices in ways that effectively rendered them as no longer eligible for services. For example, according to a program manager of a newcomer organization in Toronto, "We've had doctors say, 'Well, this person's a refugee claimant, they're going to have their claim heard while she's pregnant. I can't fire her as a patient once she's my patient, so if she ceases to be eligible for health care, I'm on the hook, so I won't take her to begin with." 65 One doctor stated that another important element of denied access to health-care services, including prenatal and postnatal services, was the indeterminacy that defined the 2014 "temporary" IFH program itself. As longer-term health-care professionals, many obstetricians perceived patients with the new "temporary" IFHP coverage as risky. As a doctor elaborated, "One of the interesting things this government did is they called it the temporary IFHP program. For many obstetricians, for example, if they pick you up now as a patient, they want to ensure that you'll still be covered thirty weeks later when you're delivering, and I think ... that terminology when you say it's temporary, is a problem.... So many obstetricians we hear just aren't touching the program whatsoever. So more and more we are seeing people who should be insured but are still being turned away from care." 66

As humanitarian actors, doctors faced the decision of having to care for oneself (i.e., reimbursement or fees for services) or caring for the refugee victim (who may or may not have coverage). ${ }^{67}$ This choice speaks to the unequal power relations between protectors and sufferers-in this case doctors and refugee claimant patients-as well as the power to discern between those who are deserving and less deserving of care, or rather, those who represent a normal presence within the space of the health-care centre, and those who do not. However, the difference that undergirds humanitarianism and irregularity leads not only to denied access to prenatal and postnatal care but also experiences of discrimination.

Discrimination, in the context of health care, can take the form of religious or cultural insensitivity, unfriendly behaviour, "racial slurs, stereotyping, and receipt of inferior care."68 Speaking on the issue of discrimination among precarious status women, a midwife stated, "I feel like there is that kind of prejudice where somebody assumes like, 'Oh she doesn't 
have OHIP, she's not going to be able to pay, she's here illegally, or without status.' So I think that's a lot of like social barriers [and] racism that people encounter in these situations." 69 A female refugee claimant shared a similar story of discrimination: "I need a family doctor, because the walk-in clinic that I used to go, they don't take care of me very well. The first that I went, the doctor that tend to me was very good on me. So the second time I went, he was not around, I went to another doctor, and was so harsh on me."7o This case of discrimination occurs in the form of indifference; this woman's concerns about the effects of a medication she was prescribed were met with neglectful care by the second doctor. Discrimination is also evident in the targeted denial of IFHP recipients, whereby doctors may choose to not register with the program in order to not serve this population. ${ }^{71}$

Quite often, as noted above, irregularization lends to negative and discriminatory assumptions about one's character. ${ }^{72}$ For example, many pregnant refugee claimant women (and other un[der]insured precarious status women), are perceived by medical professionals as "medical tourists" who deliver "anchor babies" and who abuse our already strained health-care system;73 this complements broader national discourses of refugee claimants as greedy and potentially threatening to the health-care system. ${ }^{74}$ Other professionals see pregnant refugee claimants as simply not belonging within the space of the health-care centre. Consider the case of a female refugee claimant from Mexico who was told by a hospital administrator to pay fees for the birth of her child, even though she had full health-care coverage through the IFHP. Upon learning the woman had full coverage, the administrator still required she sign a waiver rendering her responsible for any fees incurred, which created so much anxiety for the woman that she opted for a home birth, even though she felt uncomfortable with this decision. ${ }^{75}$ Since Mexico is a DCO, the administrator was more influenced by this and its relation to "bogusness" than the actual coverage itself. As a result, the administrator inscribed an irregular status onto this woman, "fixing" her as not belonging to the space of the hospital and as therefore not eligible for services, even though she was a legal temporary resident who had full health-care coverage. Drawing on Willen, this condition of irregularity within the health-care setting not only produces insecurity, but also reflects an embodiment of bio-inequality. ${ }^{76}$

Although there are cases of health-care professionals denying health-care services to refugee claimants with IFHP coverage, some also worked to liberate refugee claimants from irregularity both in the doctor's office and on the streets. Although these acts were well intentioned, I discuss below how they unintentionally maintained irregularization and conditions of irregularity.

\section{Saving Refugee Claimants: Doctors as Humanitarian Actors in the Office and on the Streets}

According to Fassin, there are three different types of life at stake: "lives to be saved, lives to be exposed, and lives to be told." 77 Doctors and nurses in Toronto act as humanitarian agents who seek to save, expose, and witness the lives of refugee claimants and relay this information to governing authorities and the public in order to liberate refugee claimants from irregularity. But their position is a powerful one; health-care professionals wield the power to designate situations as (non)emergencies and determine who receives (and who does not receive) attention or concern. In these decisions, health-care professionals can improve the welfare of individuals or diminish it. ${ }^{78}$ For those who seek to improve the welfare of refugee claimants, they are involved in saving lives as well as exposing experiences of refugee claimants, typically within doctors' offices and on the streets. However, despite these well-intentioned acts, the result did not directly challenge the irregularizing assemblage of humanitarianism, but rather sustained it, reflecting Fassin's argument that the politics of humanitarianism (saving, exposing, telling) "cannot restore equality." For him, "inequalities of lives and hierarchies of humanity surreptitiously reappear-in spite of the humanitarian agents and often without their knowing it-between the persons who intervene and the persons they assist."79 As illustrated below, in their assessments of vulnerability and deservingness, doctors perpetuated a system that ranked and irregularized refugee claimants within everyday places-the very things they were fighting against.

\section{In the Doctor's Office}

Although significant restrictions to health-care coverage were introduced through the IFHP, one exception was maintained. Under section 7 , the minister of citizenship and immigration retained the discretion to provide coverage "in exceptional and compelling circumstances." For example, one refugee claimant involved in the Charter challenge, Mr. Ayubi, was granted discretionary coverage for his diabetes-related medical services, but not for his medication, because ministerial discretion does not cover the costs of medications or immunizations unless to treat a PHPS concern or threat. ${ }^{80}$ However, as a low-income person he was unable to afford the cost of medications. Therefore, in order to survive, he had to rely on free samples of insulin provided through a community health centre. ${ }^{81}$ In their attempts to determine exceptional cases, the state demonstrates how its humanitarian stance, which aims to save lives and reduce suffering, simultaneously undermines the well-being of refugee populations.

In order to receive section 7 coverage, doctors had to witness vulnerability and plead a person's case to the federal government. For example, Dr. Banerji of the pediatric clinic 
at St. Michael's Hospital in downtown Toronto wrote a letter to the Immigration and Refugee Board (IRB) detailing the compelling and exceptional circumstances of a young mother who fled sexual abuse in Swaziland and needed access to health-care coverage to test for HIV and receive treatment for syphilis. ${ }^{82}$ Doctors also sought compassion for Joseph Bernard, a failed refugee claimant from Pakistan who had no coverage for his terminal liver cancer treatments and medications but could not be deported because he was too sick. ${ }^{83}$ Both cases were awarded exceptional medical coverage. Receiving humanitarian assistance through section 7 coverage relies upon the differentiation of some refugees as more deserving than others, and on the testimony of experts who provide an informative "rundown" of diseases and other physical ailments, which constructs a "pure helplessness." 4 In these cases, refugee claimants had to perform their "refugeeness" in order to be recognized as a legitimate subject who deserved coverage. As Ticktin notes, in this encounter between patient and doctor, "if one does not perform in the desired manner, one may be penalized and excluded." 85 Those deemed to be not deserving of assistance were reirregularized in that they were again determined to be too abnormal or problematic within the health-care setting and were forced to continue to navigate a health-care system that problematized their presence and restricted their rights. In this light, the doctor's office can be thought of as a "humanitarian space" where doctors negotiate and shape the realities of humanitarian action and the lives of those enmeshed within the humanitarian system according to principles they uphold. ${ }^{86}$ The humanitarian decision to "tell" the life of a refugee claimant-so as to "save" them-may therefore perpetuate the cleavage(s) it is trying to mend. As I discuss below, these cases were also shared in the streets to garner support from the public for the reinstatement of the IFHP.

\section{On the Streets}

The encounters that doctors have with refugee claimants in the office make them first-hand witnesses to the violence that defines the lives of refugee populations. In their attempts to rectify the injustices created through the IFHP, doctors challenged the actions of the government through interruptions of government officials, occupations of government spaces, demonstrations, and campaigns. Some examples include the National Day of Action, the occupation of Conservative MP Joe Oliver's office in downtown Toronto, and the Non-Cooperation Campaign. The goal was to educate the general public on the implications of the IFHP cuts in order to gain their support for its reinstatement. According to one doctor, advocates engaged in these public actions because the numerous letters written by national health associations to the federal government went unanswered, and calls to meet with members of the government were ignored or refused; with "nowhere else to have an engagement with them," doctors' response to this blatant disregard was to "go to the public terrain." ${ }^{7}$ Here doctors utilized "moral sentiments" 88 to direct the attention of the public to the suffering of refugee claimants and to shame the government on its treatment of this population. ${ }^{89}$

Moral sentiments aim to make the experiences of refugee populations visible by humanizing this population, or rather, by transforming them into "subjects who matter," providing what Tyler and Marciniak call "affective technologies of the "close up." 90 In speeches made at the National Day of Action in June 2014, activists shared stories of refugee claimants who were denied access to essential health-care services or coverage, "caus[ing] them to become ill and possibly die here." ${ }^{91}$ In his analysis of the IFHP protests, Beatson argues that allies employed a "victim frame" that bestowed upon refugee claimants a "victim status" that asserted helplessness and passivity and involved "the forcible creation of identities to fit a certain narrative." 92 While attempts to humanize are well intentioned, they tend to occur at the expense of history, context, politics, and individuality. Yet,humanizing strategies can also be effective in establishing some element of concern among the public by "provok[ing] publics to recognize 'the human face' of specific migrants" and to "identify with migrants as "human beings" - "as subjects who matter, "like us." 93 It can, however, "also exceptionalize the deservingness of specific categories of migrants." 94 This was particularly evident in the protests by activists.

Protestors emphasized refugee claimants' access to health care at the expense of other refugee and (forced) migrant groups, such as undocumented persons, failed refugee claimants, and $\mathrm{H} \& \mathrm{C}$ applicants, all of whom are also denied health-care coverage. For activists, the exceptionally irregularized presence and status of these populations could not be incorporated into advocacy efforts. According to a doctor involved in the National Day of Action in Toronto, "Our sole purpose was refugee claimants, and I think that's one of the reasons we were able to get the support of national health associations. If the goal was to ensure all the million people who are uninsured, 95 [they] wouldn't have gone near it. It would've worked only for refugees. So that was a strategic decision, and we stuck to it rigidly and inflexibly and it worked." 96

While it may be argued that refugees were prioritized because their authorized presence and vulnerability are palatable for the masses-whereby other uninsured groups, such as undocumented persons and failed refugee claimants, are viewed in relation to illegality and rejection-perhaps this population was also prioritized because of the very specific manner in which the IFHP cuts were conceived. According to a doctor, 
I think the way that that whole [IFHP] thing was framed was that we were all completely insured, and then one government took away coverage from this small group of people and we should give them that coverage back. But there was actually often no acknowledgement of the broader pre-existing issue because, you know, if you were non-status, the refugee health cuts don't impact you at all. You didn't have health coverage before, you don't have health coverage after. So I think there still isn't greater awareness of the fact that this is an ongoing issue and has always been an issue. 97

In this regard, emphasis was placed on refugee claimants at the expense of other groups simply because the argument was fundamentally not about access to health-care coverage, but rather, the reinstatement of a program that provided coverage to a specific group of people. In doing this, activists were not only blind (or at least dismissive) to the very real issue of health-care coverage for all residents of Canada-an issue that could have complemented, and benefitted from, the IFHP discussion-but were also essentially calling for the reinstatement of a separate health-care coverage system that, even prior to the cuts, irregularized the presence of refugee claimants within everyday health-care places..$^{8}$ The acts performed by activists therefore reflect Fraser's concept of "affirmative" politics that contest boundaries by working within them. 99 What is needed instead is a "transformative" politics that would focus on all people affected by Canada's health-care systemwhat Fraser terms the "all-affected principle"100_in order to generate a mutually supportive solidarity across boundaries and a recognition of the presence ${ }^{101}$ of all residents of Canada, to create a movement towards a truly universal form of social justice, and more specifically, a truly universal and equitable health-care system.

\section{Conclusion}

As the result of activist resistance, and a change in federal leadership, the IFHP was fully reinstated to its pre-2012 levels in April 2016; it was further expanded to cover the healthcare costs of refugees overseas in April 2017. However, the temporal effects of the IFHP cuts still linger. Caulford and Rahunathan, ${ }^{102}$ for example, discuss how refugee populations continue to be denied health-care services in Toronto, and an Access Alliance ${ }^{103}$ report claims the number of people seeking health-care services from their clinic for un(der) insured patients, including refugee claimants and patients requiring prenatal services, has significantly risen. Refugee allies have also stated their concerns regarding continued access to health care for refugee claimants. ${ }^{104}$ Therefore more research is needed on the IFHP, specifically after its reinstatement in 2016.

Canada's humanitarian system aims to alleviate suffering and assist the most vulnerable. But to do this, hierarchies are constructed to regulate and determine who deserves such forms of assistance. In this article I focus on the IFHP (from 2012 to 2016), a humanitarian health-care coverage program offered to refugee populations in Canada, to demonstrate how such hierarchies are created through irregularizing assemblages that shape how one's presence and rights are encountered and (re)negotiated, including health-care rights. ${ }^{105}$ I draw specific attention to the gendered experiences of irregularity within everyday health-care places. My analysis concludes by detailing how resistance strategies inadvertently maintain a system that irregularizes refugee claimants.

Although the focus of this article is on refugee claimants, it is important to be aware that many other populations in Canada face restricted or denied access to basic primary health-care services as a result of their constructed irregularity within the space of the health-care centre, such as nonstatus persons, newcomer permanent residents, temporary foreign workers, homeless populations, and Indigenous populations. ${ }^{106}$ Future research on irregularization would benefit from a focus on these populations so as to assist in the development of an "all-affected" ethos ${ }^{107}$ within the health-care realm that would provide the foundation on which to build a mutual solidarity and a common voice.

\section{Notes}

1 As this article was developed as part of my PhD thesis, I wish to thank Suzan Ilcan and the rest of my dissertation committee for their guidance and support. I am indebted to the participants who shared their insight and experiences with me. I also wish to thank the two anonymous reviewers for their insightful feedback and the editorial team at Refuge. The research for this article was supported by a Social Sciences and Humanities Research Council (ssHrc) doctoral fellowship.

2 Didier Fassin, "Moral Commitments and Ethical Dilemmas of Humanitarianism," in In the Name of Humanity: The Government of Threat and Care, ed. Ilana Feldman and Miriam Ticktin (Durham, NC: Duke University Press, 2010), 239.

3 Canadian Doctors for Refugee Care, the Canadian Association of Refugee Lawyers, Daniel Garcia Rodriques, Hanif Ayubi, and Justice for Children and Youth v Attorney General of Canada and Minister of Citizenship and Immigration, 18 (Federal Court, 2014 FC 651, 2014), http:// cas-cdc-www02.cas-satj.gc.ca/rss/T-356-13\%20Cdn\%20 Doctors\%20v\%20AGC\%20Judgment\%20and\%2oReasons. pdf.

4 Canadian Doctors et al., 7-8, 18.

5 Liette Gilbert, "The Discursive Production of a Mexican Refugee Crisis in Canadian Media and Policy," Journal of Ethnic and Migration Studies 39, no. 5 (2013): 827-43. 
Although the Canadian government lifted the visa requirement in December 2016, the detention of Mexicans in Canada has spiked since that time. See Anna Mehler Paperny, "Canada's Detention of Mexicans Surges after Visa Lift," Reuters, 13 June 2017, https://www.reuters.com/article/uscanada-immigration-mexico-detention/canadas-detention-of-mexicans-surges-after-visa-lift-iduskBN1942Iw.

6 Government of Canada, "Designated Countries of Origin Policy," 3 April 2017, http://www.cic.gc.ca/english/refugees/ reform-safe.asp.

7 Petra Diop, "The 'Bogus' Refugee: Roma Asylum Claimants and Discourses of Fraud in Canada's Bill C-31," Refuge 30, no.1 (2014): 67-8o.

8 Maribel Casas-Cortés, Sebastian Cobarrubias, Nicholas DeGenova, Glenda Garelli, Giorgio Grappi, Charles Heller, Sabine Hess et al., "New Keywords: Migration and Borders," Cultural Studies 29, no. 1 (2014): 71.

9 Miriam Ticktin, Casualties of Care: Immigration and the Politics of Humanitarianism in France (Berkeley: University of California Press, 2011), 121.

10 Peter Nyers, "Abject Cosmopolitanism: The Politics of Protection in the Anti-Deportation Movement," Third World Quarterly 24, no. 6 (2003): 1070.

11 Kim Rygiel, "Bordering Solidarities: Migrant Activism and the Politics of Movement and Camps at Calais," Citizenship Studies 15, no. 1 (2011): 13-14.

12 See Vicki Squire, "The Contested Politics of Mobility: Politicizing Mobility, Mobilizing Politics," in The Contested Politics of Mobility: Borderzones and Irregularity, ed. Vicki Squire, 1-26 (New York: Routledge, 2011); Kate Hepworth, "Encounters with the Clandestino/a and the Nomad: The Emplaced and Embodied Constitution of Non-Citizenship," Citizenship Studies 18, no. 1 (2014): 1-14.

13 See Bryan Turner, Status (Minnesota: University of Minnesota Press, 1989), 2-5.

14 See Hepworth, "Encounters," 4.

15 Daniel O'Connor and Suzan Ilcan, "Assemblages: Space and Sociation," Space and Culture 4, no. 7-9 (2001): 1-3.

16 Rygiel, "Bordering Solidarities," 13-14.

17 Rygiel, "Bordering Solidarities," 14.

18 See Suzan Ilcan, "Paradoxes of Humanitarian Aid: Mobile Populations, Biopolitical Knowledge, and Acts of Social Justice in Osire Refugee Camp," in Mobilities, Knowledge and Social Justice, ed. Suzan Ilcan (Montreal and Kingston: McGill-Queen's University Press, 2013), 79.

19 See Fassin, "Moral Commitments"; Liisa Malkki, "Speechless Emissaries: Refugees, Humanitarianism, and Dehistoricization," Cultural Anthropology 11, no. 3 (1996): 377404; Ilcan, "Paradoxes," 179.

20 Fassin, "Moral Commitments," 239.

21 Michael Barnett and Thomas Weiss, "Humanitarianism: A Brief History of the Present," in Humanitarianism in Question: Politics, Power, Ethics, ed. Michael Barnett and Thomas Weiss (New York: Cornell University Press, 2008), 3-4.
22 Michael Barnett and Jack Snyder, "The Grand Strategies of Humanitarianism," in Humanitarianism in Question: Politics, Power, Ethics, ed. Michael Barnett and Thomas Weiss, 143-71 (New York: Cornell University Press, 2008), 143.

23 B.S. Chimni, "Globalization, Humanitarianism and the Erosion of Refugee Protection," Journal of Refugee Studies 13, no. 3 (2000): 243-63; Roberto Belloni, "The Trouble with Humanitarianism," Review of International Studies 33 (2007): 451-74.

24 Suzan Ilcan, Marcia Oliver, and Laura Connoy, "Humanitarian Assistance, Refugee Management, and Self-Reliance Schemes," in Transnational Social Policy: Social Welfare in a World on the Move, ed. Luann Good Gingrich and Stefan Köngeter, 152-78 (New York: Routledge); Suzan Ilcan, Marcia Oliver, and Laura Connoy, "Humanitarian Assistance and the Politics of Self-Reliance: Uganda's Nakivale Refugee Settlement." CIGI Paper Series No. 86, 18 December 2015, https://www.cigionline.org/publications/humanitarian-assistance-and-politics-self-reliance-ugandas-nakivale-refugee-settlement.

25 Malkki, "Speechless Emissaries," 378.

26 Malkki, "Speechless Emissaries."

27 See Fassin, "Moral Commitments," 254.

28 Ticktin, Casualties of Care, 261.

29 Ilcan, "Paradoxes of Humanitarian Aid"; Miriam Ticktin, "Where Ethics and Politics Meet: The Violence of Humanitarianism in France," American Ethnologist 33, no. 1 (2006): 33-49.

30 William Walters, "Foucault and Frontiers: Notes on the Birth of the Humanitarian Border," in Governmentality: Current Issues and Future Challenges, ed. Ulrich Bröckling, Susanne Krasmann, and Thomas Lemke, 138-64 (New York: Routledge, 2010).

31 Malkki, "Speechless Emissaries," 388.

32 Interview with lawyer, 7 October 2015, Toronto.

33 Rygiel, "Bordering Solidarities", 13-14.

34 Cited in Chimni, "Globalization," 254.

35 Squire, "Contested Politics," 14.

36 Hepworth, "Encounters," 4-7.

37 O'Connor and Ilcan, "Assemblages."

38 Paloma Villegas, "Assembling a Visa Requirement against the Mexican 'Wave': Migrant Illegalization, Policy and Effective 'Crises' in Canada," Ethnic and Racial Studies 36, no. 12 (2013): 2202.

39 Martin Müller, "Assemblages and Actor-Networks: Rethinking Socio-material Power, Politics and Space," Geography Compass 9, no. 1 (2015): 27.

40 Diop, "Bogus' Refugee”; Cynthia Levine-Rasky, "Designating Safety, Denying Persecution: Implication for Roma Refugee Claimants in Canada," Journal of Immigration and Refugee Studies (2017): 1-18. DOI: 10.1080/15562948.2017.1298873.

41 For a detailed history of the IFHP, see Ruby Dhand and Robert Diab, "Canada's Refugee Health Law and Policy from a Comparative, Constitutional, and Human Rights 
Perspective," Canadian Journal of Comparative and Contemporary Law 1 (2015): 351-406.

42 Increasing program expenses were a result of changes made to Ontario's health insurance plan (OHIP), which denied coverage to temporary residents (Steve Sansom, "Refugee Claimants, OHIP Eligibility, and Equality," Journal of Law and Social Policy 12, no. 8 [1997]: 202-32), and extended processing times (Ashley Burke, "Legacy Claimants' Hoping for Long-Awaited Refugee Hearings," СвС News, 1 May 2017, http://www.cbc.ca/news/canada/ottawa/ ottawa-forgotten-refugee-new-task-force-1.4091221).

43 Canadian Doctors et al.

44 Scott Armstrong, "Scott Armstrong on Protecting Canada's Immigration System Act," 1 June 2012, https://openparliament.ca/debates/2012/6/1/scott-armstrong-1/only/.

45 Government of Canada, "Speaking Notes for Chris Alexander, Canada's Citizenship and Immigration Minister at the News Conference Regarding Canada's Asylum System," 22 January 2014, https://www.canada.ca/en/news/ archive/2014/o1/speaking-notes-chris-alexander-canadacitizenship-immigration-minister-news-conferenceregarding-canada-asylum-system.html?=undefined\&wbdi sable $=$ true.

46 Government of Canada, "Speaking Notes for Chris Alexander.

47 Interestingly, during this time the Canadian government was providing medical services to refugees overseas. See Laura Payton, "Red Crescent to Handle \$2M in Canadian Aid to Syrians," CBC News, 1 October 2012, http://www.cbc. $\mathrm{ca} /$ news/politics/red-crescent-to-handle-2m-in-canadianaid-to-syrians-1.1148398.

48 Examples of PHPS threat/concern include: TB, HIV, malaria, measles, and chicken pox. A condition posing a risk includes mental health conditions that cause harm to the individual or others, Canadian Doctors et al., 25.

49 Government of Canada, "Interim Federal Health Program Reform: Examples of Coverage for Selected Conditions," 2012, http://www.refugeehealth.ca/sites/default/ files/IFH-\%2oExamples\%20of\%2oCoverage $\% 20$ for $\% 20$ Selected\%2oConditions.pdf, 5-6.

50 Canadian Doctors et al., 23-4.

51 Government of Canada, "Interim Federal Health," 5-6.

52 Interview with doctor, 10 November 2015, Toronto.

53 Canadian Doctors et al.; Canadian Association of Refugee Lawyers, "Health Care for Refugees," 2013, http://www.carlacaadr.ca/our-work/issues/IFHP.

54 Government of Canada, "Speaking Notes."

55 Jennifer Hyndman, "Introduction: The Feminist Politics of Refugee Migration," Gender, Place and Culture 17, no. 4 (2010): 454; Rupaleem Bhuyan, Bethany Osborne, Sajedeh Zahraei, and Sarah Tarshis, "Unprotected, Unrecognized: Canadian Immigration Policy and Violence against Women, 2008-2013," Migrant Mothers Project, 2014, 10-11.

56 Tara Carman and Anita Elash, "Gender Persecution the Top Reason Women Seek Asylum in Canada," CBC
News, 7 February 2018, http://www.cbc.ca/news/canada/ asylum-seekers-data-gender-persecution-1.4506245.

57 Erica Marie See, "The Treatment of Women under Canada's Gender Guidelines in Judicial Reviews of GenderRelated Refugee Claims: 2003-2013" (LLD diss., University of Ottawa, 2016), 26.

58 Interview with executive director, 26 November 2015, Toronto.

59 Olivia Salcido and Cecilia Menjívar, "Gendered Paths to Legal Citizenship: The Case of Latin-America Immigrants in Phoenix, Arizona," Law \& Society Review 46, no. 2 (2012): 342 .

6o Rupaleem Bhuyan, Bethany Osborne, and Janet Cruz, “'Once You Arrive, Se Te Sala Todo' (Everything Is Salted): Latina Migrants' Search for 'Dignity and a Right to Life' in Canada," Journal of Immigrant and Refugee Studies 4 (2016): 413.

61 Government of Canada, "Section 5: Gender-Based Analysis of the Impact of the Immigration and Refugee Protection Act," 28 October 2013, http://www.cic.gc.ca/english/ resources/publications/annual-report-2013/section5.asp.

62 CLeO, "Humanitarian and Compassionate (H\&C) Applications and Refugee Claims: How Are They Different?," http://www.cleo.on.ca/en/publications/hcref/what-aresome-other-differences-between-hc-application-and-refugee-claim.

63 Interview with lawyer, 11 November 2015, Toronto.

64 Interview with doctor, 20 October 2015, Toronto.

65 Interview with program manager, 8 October 2015, Toronto.

66 Interview with doctor, 19 October 2015, Toronto.

67 Karine Vanthuyne, Francesca Meloni, Monica RuizCasares, Cécile Rousseau, and Alexandra Ricard-Guay, "Health Workers' Perceptions of Access to Care for Children and Pregnant Women with Precarious Immigration Status: Health as a Right or a Privilege?," Social Science \& Medicine 93, no. 3 (2013): 79.

68 Grace Pollock, Bruce Newbold, Ginette Lafrenière, and Sara Edge, "Discrimination in the Doctor's Office: Immigrants and Refugee Experiences," Critical Social Work 13, no. 2 (2012): 63 .

69 Interview with midwife, 22 January 2016, Toronto.

70 Interview with refugee claimant, 11 March 2016, Toronto.

71 Interview with doctor, 20 October 2015, Toronto.

72 See Engin Isin, Being Political: Genealogies of Citizenship (Minneapolis: University of Minnesota Press, 2002), 34.

73 Cited in Vanthuyne et al., "Health Workers," 81.

74 Government of Canada 2014, "Speaking Notes."

75 Sonal Marwah, "Refugee Health Care Cuts In Canada: System Level Costs, Risks and Responses," Wellesley Institute Policy Paper, 2014.

76 Sarah Willen, "Do 'Illegal' Im/migrants Have a Right to Health? Engaging Ethical Theory as Social Practice at a Tel Aviv Open Clinic," Medical Anthropology Quarterly 25, no. 3 (2011): 304.

77 Fassin, "Moral Commitments," 240. 
78 Barnett and Weiss, "Humanitarianism," 42.

79 Fassin, "Moral Commitments," 255.

80 Canadian Doctors et al., 26.

81 Canadian Doctors et al., 10-11; interview with lawyer, 21 October 2015.

82 Global News, "Up in Arms: Doctors Protest for Refugee Health Care," 16x9 Program, 5 October 2012, https://www. youtube.com/watch?v=Sv6bjmPogyI.

83 Heather Yourex-West, "Calgary Doctor Appeals for Help after Dying Patient Denied Health Care," Global News, 24 March 2015, https:/globalnews.ca/news/1901576/calgary-doctor-appeals-for-help-after-dying-patient-deniedhealth-care/; Yourex-West, "Government Restores Health Coverage to Refugee Dying of Cancer," Global News, 19 May 2015, http://globalnews.ca/news/2006551/governmentrestores-health-coverage-to-refugee-dying-of-cancer/.

84 Malkki, "Speechless Emissaries," 390.

85 Ticktin, "Where Ethics and Politics Meet," 43.

86 Dorothea Hilhorst and Bram Jansen, "Humanitarian Space as Arena: A Perspective on the Everyday Politics of Aid," Development and Change 41, no. 6 (2010): 1117-18, 1120.

87 Interview with doctor, 10 November 2015, Toronto.

88 Didier Fassin, Humanitarian Reason: A Moral History of the Present (Berkeley: University of California Press, 2012), 1.

89 Canadian Doctors for Refugee Care, "Day of Action Toronto 2014: Canadian Doctors for Refugee Health Care," https://www.youtube.com/watch?v=Ag6jypRd-jo; Las Perlas Tv, "Canadian Doctors for Refugee Care," https://www. youtube.com/watch?v=C 7 Pgow6SlhY.

90 Imogen Tyler and Katarzyna Marciniak, "Immigrant Protest: An Introduction," Citizenship Studies 17, no. 2 (2013): 152.

91 Canadian Doctors for Refugee Care, "Day of Action."

92 Jesse Beatson, "The Stories We Tell about Refugee Claimants: Contested Frames of the Health-Care Access Question in Canada," Refuge 32, no. 3 (2016): 130.

93 Tyler and Marciniak, "Immigrant Protest," 152-3.

94 Tyler and Marciniak, "Immigrant Protest," 152-3.

95 Although the number of uninsured persons in Canada is difficult to measure, according to one doctor, "There might be about two hundred thousand people in the [Greater Toronto Area] that don't have access to health care because of their immigration status" (interview with doctor, 20 October 2015, Toronto), while an estimated five hundred thousand people in Canada do not have access to coverage (oHIPforAll.ca, "Why oHIP for All?" http://ohipforall.ca/ why-ohip-for-all/).

96 Interview with doctor, 15 November 2015, Toronto.

97 Interview with doctor, 20 October 2015, Toronto; See Laura Connoy, "Borderzones and the Politics of Irregularisation: The Interim Federal Health Program and Toronto's Everyday Places of Healthcare," International Journal of Migration and Border Studies, forthcoming, http://www.inderscience.com/info/ingeneral/forthcoming.php?jcode=IJMBS.
98 Interview with doctor, 20 October 2015, Toronto; see Marie McKeary and Bruce Newbold, "Barriers to Care: The Challenges for Canadian Refugees and Their Health Care Providers," Journal of Refugee Studies 23, no. 4 (2010): 523-45.

99 Nancy Fraser, Scales of Justice: Reimaging Political Space in a Globalizing World (New York: Columbia University Press, 2008), 22-4.

100 Fraser, Scales of Justice.

101 It is important to keep in mind that all refugee populations in Canada, including undocumented persons and failed claimants, contribute to the public funding of health care through sales tax (Vanthuyne et al., "Health Workers," 84). In this light, the acknowledgement of presence also offers an important grounded claim of "being here" and of therefore contributing to health care. In other words, their presence establishes their right to health care.

102 Paul Caulford and Sumathy Rahunathan, "Children and Youth New to Canada: Medical Care Denied-A Growing Health Poverty" (Canadian Centre for Refugee \& Immigrant HealthCare Report, 2017).

103 Sideeka Narayan, Monika Dalmacio, Tanzil Islam, Simone Stothers, and Buvani Sivagnanasunderam, NonInsured Walk-In Clinic (NIWIC) Annual Report, (Access Alliance, 2017), http://accessalliance.ca/wp-content/ uploads/2017/12/NIWIC-Annual-Report-2016-2017.pdf.

104 Stephanie Levitz, "Access Concerns Persist as Expanded Refugee Health-Care Coverage Begins," Globe and Mail, 1 April 2016, https://beta.theglobeandmail.com/news/national/ concerns-over-access-persist-as-expanded-refugeehealth-care-coverage-begins/article29492803/?ref=http:// www.theglobeandmail.com\&.

105 See Laura Connoy, "Borderzones and the Politics of Irregularisation: The Interim Federal Health Program and Toronto's Everyday Places of Healthcare," International Journal of Migrant and Border Studies 4, no. 1/2 (2018): 144-62.

106 Erika Khandor, Kate Mason, Catherine Chambers, Kate Rossiter, Laura Cowan, and Stephen Hwang, "Access to Primary Health Care among Homeless Adults in Toronto, Canada: Results from the Street Health Survey," Open Med 5, no. 2 (2011): 94-103; Bryan Labby, "Unequal Treatment: First Nations Woman Denied Medical Coverage Readily Available to non-Aboriginals," свC News, 29 May 2017, http://www.cbc.ca/news/canada/calgary/first-nations-siksika-cleft-palate-indigenous-funding-denied-discrimination-1.4131449; Narayan et al., Non-Insured.

107 Fraser, Scales of Justice.

Laura Connoy recently obtained a PhD in sociology from the University of Waterloo, Ontario. She is an instructor at Saint Mary's University, Nova Scotia. The author may be contacted atlaura.connoy@gmail.com. 